\title{
A Brief Note on New Spirituality in Liquid Modernity
}

\author{
Silvia Rivadossi \\ Department of Asian North African Studies \\ Ca' Foscari University of Venice \\ Dorsoduro, 3462 \\ 30123 Venice, Italy
}

\begin{abstract}
This brief note discusses the search for spirituality in post-modern societies, mainly with reference to the Japanese context. It will become clear that the study of contemporary dynamics needs to take the religious/spiritual aspect into account, by recognizing what is happening on the border between the material and the spiritual world and what needs are being met by the various new spirituality movements.
\end{abstract}

Keywords: New spirituality, liquid modernity, self-cultivation, Japan

\section{The reappearance of spirituality in a liquefied reality}

In 1975 Carmen Blacker - the best-known non-Japanese scholar of Japanese shamanic figures - closed her monograph with the following words, predicting the progressive disappearance of shamans in Japan in the near future:

The vision of another plane utterly different from our own, ambivalent, perilous and beyond our control, has faded. Instead the universe has become one-dimensional; there is no barrier to be crossed, no mysteriously other kind of being to be met and placated. [...] The mystery and ambivalent peril which surrounded the holy has gone, and with it the barrier which divided sacred from profane. When the view of the other world fades, and its inhabitants dwindle to the predictable regularities called the laws of nature, the shaman and his powers are no longer needed. (Blacker 1986, 315). Blacker's theory is in line with the perspective of those scholars who predicted the inevitable decline of the sacred as a consequence of the processes of modernization and globalization. According to this view, the world has become onedimensional and there are no longer any barriers to overcome in order to get in touch with other-than-human entities; rites have lost their meaning, becoming mere forms of entertainment; humans have taken full control of all forces and natural events; and the sacred is being exploited and subjected to the needs and rules of the market and mass media.

It is undeniable that, as Zygmunt Baumann (2000) theorized, the reality we live in is a liquid one, where borders and boundaries became fluid and individuals appear to be on an endless search for multiple experiences and ways to (re)organize their identity. However, in this search for identity and - to a certain degree - solidity, individuals also require the religious sphere to play a role and to offer them concepts, symbols, and techniques by which they can reconstruct themselves.

Therefore, despite all the theories about an imminent and complete secularization, liquid modernity is also witnessing the re-emergence of spirituality as - we might say - a melted form of religion.

As a matter of fact, there is one border that has not liquified and which continues to be perceived as important: the one between the physical and the spiritual worlds. Only a few people are seen as being able to find an opening along this border, allowing the inhabitants of the two worlds to establish a dialogue and an exchange that is generally a source of knowledge and healing, mainly for the inhabitants of the physical world. On the border between the two worlds, these spiritual actors (spiritual therapists, "shamans", spiritual counselors, spiritual guides...) can build a space for action and interaction by which to gain knowledge and remedies to solve problems of various kinds.

In post-industrial societies there is an undeniable demand for such actors specialized in enabling contacts with energies, spirits or deities and able to heal the individual by reconnecting all his/her fragmented components and giving him/her tools to be used autonomously. What these figures offer is holistic healing: they aim to rebalance and re-harmonize situations that are perceived as being precarious, or, better, that they themselves have defined and have helped others perceive as precarious. 
The border between worlds thus becomes a space in which the individual can find the necessary tools to try to rebuild a sort of solidity and thus avoid insecurity and uncertainty which - according to Baumann, who here refers to an essay by Pierre Bourdieu (La precaritéestaujourd'huipartout) - is "the most widespread (as well as the most painfully felt) feature of contemporary life conditions" $(2000,161)$.

\section{A spiritual revolution}

From the Seventies, at first in the United States and then in other economically advanced areas of the world such as Western Europe and Japan, we have witnessed a gradual movement away from religion - especially from religions centred on the idea of salvation - and toward a new spirituality or "alternative spirituality", which Shimazono Susumu defines as "new spirituality movements and culture" (2004, 296-299). This process reached a peak in the Nineties; during the new century, new spirituality movements and culture lost the characteristic of being something "alternative" and became part of the mainstream.

"The term 'new spirituality' today designates the third, gaseous, ethereal state of religious matter" (Motak 2009, 135). It is impossible to give a universally valid definition of the term, since this "gaseous" new spirituality encompasses a wide range of movements and expressions, as a polythetic class. The category in question is thus best described through those elements shared by the majority of expressions it includes.

The fulcrum of new spirituality is the individual and his/her search for a new definition of the self. Traditional religions that speak to a community are therefore unable to play a role in this new process of identity construction. On the contrary, in new spirituality the individual is guaranteed a direct, privileged and personal relationship with a nonhuman entity (spirits, gods or energies) and - according to the narratives of these movements - access to powers and abilities that are already present in him/her, waiting to be awakened.

New spirituality movements and culture thus emphasize the aspect of self-cultivation and transformation: through various techniques or practices the individual is believed to be able to reach his/her true self and to obtain spiritual healing. The transformation of consciousness is considered extremely important since it can lead to the creation of a harmonious relationship with other individuals, thereby contributing to the transformation of the entire universe. Concerning this last point, it is necessary to note that the reappearance of spirituality in the post-industrial world can also be understood as a reaction to the environmental costs of the process of industrialization: increasing pollution and ecological disasters have led to the emergence of a new ecological awareness that is accompanied by a reflection on healing methods, focusing on holistic healing, which presupposes the erosion of the dualism between spirit and matter and, therefore, the reconciliation between religion and science.

The transition "from salvation to spirituality", to quote the title of Shimazono's book (2004), is therefore closely connected to the individual desire for self-cultivation and self-affirmation. In the uncertainty of liquid modernity, the spaces built by new spirituality movements on the border between the two worlds serve this very aim, namely: to offer the possibility of building a more solid and resistant identity, where all the components are in harmony with each other (within the individual) and with the universe.

To describe what has taken place in Japan, scholars talk about a "spirituality boom" that faded at the end of the first decade of the new century (see, for example, Gaitanidis 2012b; Horie 2009; Itō, Kashio, \&Yumiyama 2004; Prohl 2007; Sakurai 2009a; Shimazono 2007, 2012b; Shimazono\& Graf 2012).

However, considering that new spirituality movements and culture have left traces that continue to be felt in different forms nowadays, it would be better to talk about a "spiritual revolution", as suggested by Paul Heelas and Linda Woodhead, who studied the process in the United Kingdom (2005). The dynamics they describe are the same observable in other post-industrial countries, such as the United States and Japan.

As the two authors explain, the growth of the various expressions of spirituality - the so-called "subjective turn" owes much to their ability to "cater for the values and expectations, potentialities and vulnerabilities of those who attach importance to subjective-life as a primary source of significance" $(2005,82)$. The point lies, therefore, in the difference between two ways of living and experiencing the sacred in connection to the self, two ways that correspond to "religion" and "spirituality". While religion proposes the mode of "life-as", that is a life lived in accordance with predefined roles, spirituality emphasizes "subjective-life": a life lived in profound connection within oneself, where experiences are the key, in line with the liquefaction and individualization that characterize contemporary society.

In the study of this turn "away from being told what or how to be yourself to having the freedom to be yourself" (Heelas \& Woodhead, 2005, 95), two aspects need further exploration. 
First, in new spirituality women seem to play a primary role, both as leaders and as seekers (see, for example, Gaitanidis 2012a, Komatsu 2017 and Sointu\& Woodhead 2008). Second, the role of mass media in the creation and diffusion of new spirituality movements and culture cannot be overlooked (see, for example, Watanabe, Shimazono\& Miyazaki 2008).

The spiritual revolution just described does not occur in the religious sphere alone, since this does not exist in isolation and independently of the social, political and economic sphere; rather, the two are part of a complex network of relationships. This is particularly clear when it comes to the process of commodification of spiritual ideas, concepts, goods, and practices (see, for example, Gaitanidis 2011, Gauthier \&Martikainen 2013, Sakurai 2009b and Usunier\& Stolz 2014).

In their emblematic study, Jeremy Carrette and Richard King argue that "In a context where brands and images are becoming more important than the products themselves, 'spirituality' has become the new currency in the task of winning human minds and hearts" $(2005,25)$. This is evident, for instance, from the many publications devoted to meditation (especially mindfulness), self-healing, yoga, and channeling. The selling of spirituality also takes the form of various seminars and workshops that offer, among other things, experiences related to the alteration of consciousness and the knowledge of self-healing and self-cultivation practices. Moreover, spirituality is also frequently used to advertise many different products (see Marmor-Lavie, Stout \& Lee 2009).

All these elements are proof of the fact that "Spirituality has arrived in the corporate marketplace and all that is required is a desire to consume" (Carrette\& King 2005, 53).

New spirituality is consumer-oriented, reflecting the characteristics and needs of potential consumers and, in a certain sense, contributing to the creation of these same needs. Indeed, this process of commodification of spirituality succeeds in making the consumer perceive a particular problem and the consequent need to look for a remedy. Stating that a certain herbal tea helps to regain one's balance and harmony or that a certain musical vibration can eliminate tensions actually amounts to telling the consumer that he/she is in a state of imbalance and distress that must be resolved and can be resolved through the use of that particular product or technique.

\section{Final remarks}

To better grasp and understand what is going on in post-industrial societies, it is essential to recognize, take into account and analyze the many uses of the discourse on spirituality and the various products and cultural texts in which such a spiritual need emerges: from advertising to films, from novels to manga, from works of art to musical pieces.

As Arjun Appadurai wrote, "many lives are now inextricably linked with representations, and thus we need to incorporate the complexities of expressive representations (film, novels, travel accounts) into our ethnographies, not only as technical adjuncts but as primary material with which to construct and interrogate our own representations" (1996, 63-64).

Only then will it be possible to reconstruct the contemporary discourse on spirituality, its characteristics and genealogy.

\section{References}

Appadurai, A. (1996). Modernity at large. Cultural dimensions of globalization. Minneapolis: University of Minnesota Press.

Baumann, Z. (2000). Liquid modernity. Cambridge: Polity Press.

Blacker, C. (1986). The catalpa bow. A study of shamanistic practices in Japan. (2a ed.). London: Allen \& Unwin.

Carrette, J., \& King, R. (2005). Selling spirituality. The silent takeover of religion. London; New York: Routledge.

Gaitanidis, I. (2011). At the forefront of a 'spiritual business'. Independent professional spiritual therapists in Japan. Japan Forum, 23(2), 185-206.

Gaitanidis, I. (2012a). Gender and spiritual therapy in Japan. International Journal for the Study of New Religions, $3(2), 269-288$.

Gaitanidis, I. (2012b). Spiritual therapies in Japan. Japanese Journal of Religious Studies, 39(2), 353-385.

Gauthier, F., \&Martikainen, T. (Eds.) (2013). Religion in consumer society. Brands, consumers, and markets. Farnham: Ashgate.

Heelas, P., \& Woodhead, L. (2005). The spiritual revolution. Why religion is giving way to spirituality. Oxford: Blackwell.

Horie, N. (2009). Spirituality and the spiritual in Japan. Translation and transformation. Journal of Alternative Spiritualities and New Age Studies, 5. 
Itō, M., Kashio, N., \&Yumiyama, T. (2004). Supirichuariti no shakaigaku: gendaisekai no shūkyōsei no tankyū. Kyōto: Seikaishisōsha.

Komatsu, K. (2017). Spirituality and women in Japan. Japanese Journal of Religious Studies, 44, 123-138.

Marmor-Lavie, G., Stout, P. A., \& Lee, W.N. (2009) Spirituality in advertising: A new theoretical approach, Journal of Media and Religion, 8(1), 1-23.

Motak, D. (2009). Postmodern spirituality and the culture of individualism. In T. Ahlbäck (Ed.), Postmodern spirituality (pp. 129-141). The Donner Institute: ÅboAkademi.

Prohl, I. (2007). The spiritual world. Aspects of new age in Japan. In D. Kemp, \& J. Lewis (Eds.), Handbook of new age (pp. 359-374). Leiden: Brill.

Sakurai, Y. (2009a). Gendainihonshakai to supirichuariti-būmu. In Y. Sakurai (Ed.), Karuto to supirichuariti. Gendainihon ni okeru 'sukui' to 'iyashi' no yukue (pp. 245-275). Kyōto: MineruvaShobo.

Sakurai, Y. (2009b). Rei to kane: Supirichuaru-bijinesu no kōzō. Tōkyō: Shinchōsha.

Shimazono, S. (2004). From salvation to spirituality. Popular religious movements in modern Japan. Melbourne: Trans Pacific Press.

Shimazono, S. (2007). Supirichariti no kōryū. Shinreiseibunka to sonoshūhen. Tōkyō: Iwanami Shoten.

Shimazono, S. (2012). Gendaishūkyō to supirichariti. Tōkyō: Kōbundō.

Shimazono, S., \& Graf, T. (2012). The rise of new spirituality. In I. Prohl, \& J. Nelson (Eds.), Handbook of contemporary Japanese religions (pp. 459-485). Leiden: Brill.

Sointu, E., \& Woodhead, L. (2008). Spirituality, Gender, and Expressive Selfhood. Journal for the Scientific Study of Religion, 47(2), 259-276.

Usunier, J.C., \& Stolz, J. (Eds.) (2014). Religions as brands. New perspectives on the marketization of religion and spirituality. Farnham: Ashgate.

Watanabe, N., Shimazono, S., \& Miyazaki T. (2008). Masu media to supirichuarubūmu. In KokusaiShūkyōKenkyūjo (Ed.), Media gaumidasukamigami (pp. 1-39). Tōkyō: Akiyama Shoten. 